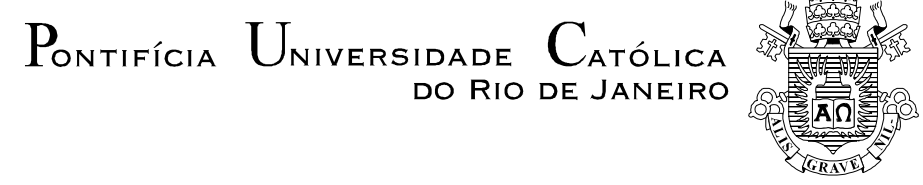

Erick Costa e Silva Talarico

\title{
Production of Boron doped single walled carbon nanotubes via different precursors
}

Thesis presented to the Programa de PósGraduação em Física of the Departamento de Física, PUC-Rio as partial fulfillment of the requirements for the degree of Mestre em Física.

Advisor: Prof.Fernando Lázaro

Co-Advisor: Prof. Marcelo Eduardo Huguenin

Rio de Janeiro

September 2012 
Erick Costa e Silva Talarico

\section{Production of Boron doped single walled carbon nanotubes via different precursors}

Thesis presented to the Programa de Pós-Graduação em Física of the Departamento de Física do Centro Técnico Científico da PUC-Rio, as partial fulfillment of the requirements for the degree of Mestre.

Prof. Fernando Lázaro Freire Júnior Advisor

Departamento de Física - PUC-Rio

Prof. Marcelo Eduardo Huguenin Maia da Costa

Co-Advisor

Departamento de Física - PUC-Rio

Prof. André Silva Pimentel Departamento de Química - PUC-Rio

Prof. Stanislav Moshkalev UNICAMP

José Eugenio Leal

Coordinator of the Centro Técnico Científico - PUC-Rio

Rio de Janeiro, 3/9/2012. 
All rights reserved

Erick Costa e Silva Talarico

The author has graduated in Physics from Pontifícia Universidade Católica do Rio de Janeiro in 2010

Bibliographic data

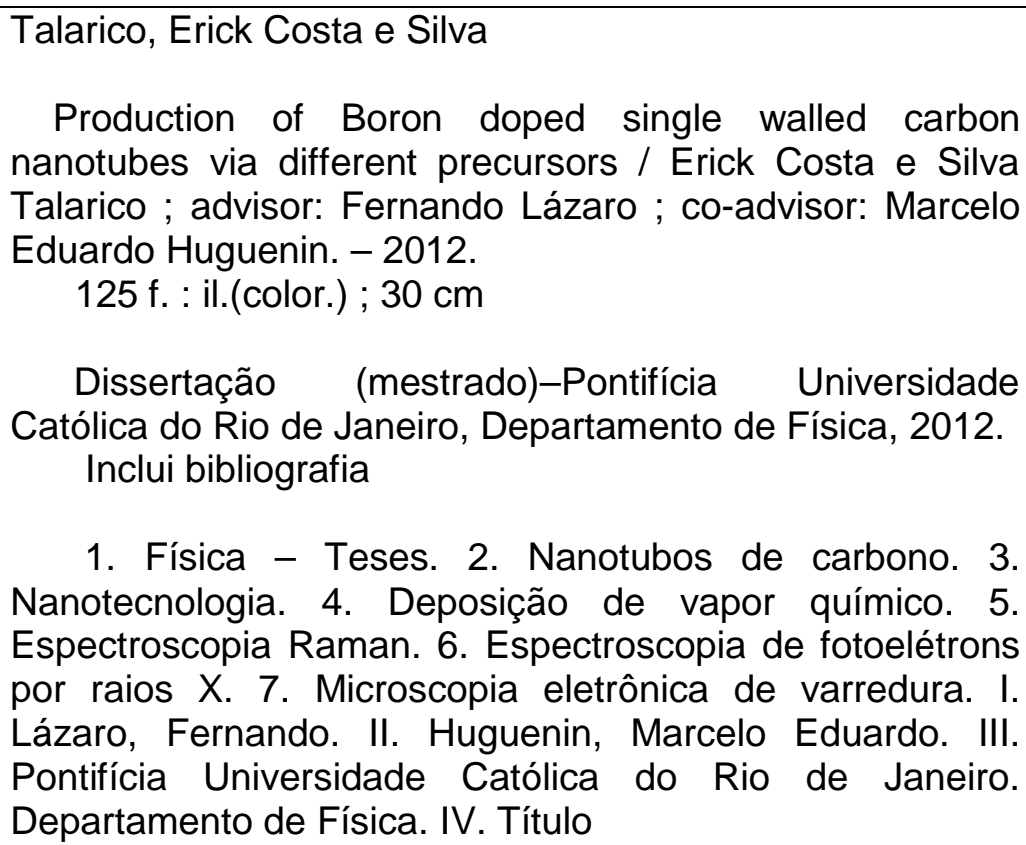

Production of Boron doped single walled carbon nanotubes via different precursors / Erick Costa e Silva Talarico ; advisor: Fernando Lázaro ; co-advisor: Marcelo Eduardo Huguenin. - 2012.

125 f. : il.(color.) ; $30 \mathrm{~cm}$

Dissertação (mestrado)-Pontifícia Universidade Católica do Rio de Janeiro, Departamento de Física, 2012. Inclui bibliografia

1. Física - Teses. 2. Nanotubos de carbono. 3. Nanotecnologia. 4. Deposição de vapor químico. 5. Espectroscopia Raman. 6. Espectroscopia de fotoelétrons por raios X. 7. Microscopia eletrônica de varredura. I. Lázaro, Fernando. II. Huguenin, Marcelo Eduardo. III. Pontifícia Universidade Católica do Rio de Janeiro. Departamento de Física. IV. Título 
To my Family, girlfriend Jéssica Felix Macêdo and to God, For the strength. 


\section{Acknowledgments}

First I thank my advisors Fernando Lázaro e Marcelo Huguenin for all the patience and belief in my work. I thank them for being friends besides advisors, and always having the time to help and discuss experimental issues.

I thank CNPq and PUC-Rio for the support, without which the present work wouldn't be possible to be accomplished.

I thank my girlfriend for supporting and helping me in editing the present work. Without her help, maybe it would not be possible to accomplish everything that have been accomplished in this work.

I thank my colleagues and the staff in Van de Graaff Building for all the help with technical problems, and willing to exchange experiences, and build a constructive environment in the Lab, in which everyone worried about each other's experiments, and looked forward for their success.

I thank my family for supporting me to work on my Master Thesis, and putting up with my absence when I had to stay late at the Lab.

I thank my boss at Petrobras for supporting me to finish my Master's work, and for the patience.

Finally, and one of the most important thanks, I thank God for all the strength and faith even when there was no hope that the present work could ever be accomplished. 


\section{Resumo}

Talarico, Erick Costa e Silva; Freire Júnior, Fernando Lázaro; Huguenin, Marcelo Eduardo. Produção de nanotubos de carbono de paredes simples dopados com Boro a partir de diferentes precursores. Rio de Janeiro, 2012. 125p. Dissertação de Mestrado - Departamento de Física, Pontifícia Universidade Católica do Rio de Janeiro.

Nanotubo de Carbono é um alótropo do Carbono cujo caráter 1D confere-lhe propriedades mecânicas, eletrônicas, térmicas, ópticas excepcionais. Por isso que cientistas têm estudado este material intensamente, tanto do ponto de vista teórico, como de um ponto de vista experimental. Um dos interesses de pesquisa experimental é se conseguir produzir de forma controlada Nanotubos de Carbono com propriedades otimizadas, para aplicações específicas. Outra linha de pesquisa experimental que existe é a de sintetizar Nanotubos de Carbono dopados, com o objetivo de se criar Nanotubos com novas propriedades físicas. A presente dissertação de Mestrado concentra-se na síntese de especificamente Nanotubos de paredes simples dopados com Boro, e tem como objetivos avaliar a viabilidade de se produzir tais Nanotubos dopados com níveis de dopagem controlados, assim como estudar as novas propriedades físicas que surgem em Nanotubos dopados. Inicialmente, neste trabalho será conduzida uma revisão da atual literatura científica sobre Nanotubos de Carbono, com foco nas diferenças físicas entre nanotubos puros e dopados. Em seguida, o aparato experimental e a metodologia utilizada serão descritos. Por fim, os resultados experimentais serão analisados objetivando-se entender a nova física por trás dos nanotubos dopados com Boro, assim como responder à questão se o método adotado conseguiu produzir Nanotubos dopados de forma controlada.

\section{Palavras chave}

Nanotubos de Carbono; nanotecnologia; deposição de vapor químico; espectroscopia Raman; espectroscopia de fotoelétrons por raios X; microscopia eletrônica de varredura. 


\section{Abstract}

Talarico, Erick Costa e Silva; Freire Júnior, Fernando Lázaro (Advisor); Huguenin, Marcelo Eduardo (Co-advisor). Production of Boron doped single walled carbon nanotubes via different precursors. Rio de Janeiro, 2012. 125p. MSc. Dissertation - Departamento de Física, Pontifícia Universidade Católica do Rio de Janeiro.

Carbon nanotube is a carbon allotrope whose unique characteristic is its 1D geometry, and that has outstanding mechanical, electronic, thermal, optical properties. Nonetheless, this material has been deeply studied from theoretical and experimental standpoints. From the experimental point of view, there is the interest to create a controlled synthesis of Carbon Nanotubes with optimized physical properties for specific purposes. Another contemporary research interest is on the synthesis of doped Carbon Nanotubes, with the objective of inducing new properties on the Nanotube. This thesis work focuses on the synthesis of, specifically, Boron doped Single Walled Carbon Nanotubes, and aims to study the feasibility of producing Carbon Nanotubes with controlled doping levels by changing the precursor substance, and to understand the new physical properties that arise from the incorporation of Boron heteroatoms on the Carbon Nanotube structure. In this thesis work, a review of the current literature about Carbon Nanotube science is conducted, with focus on the differences in properties between pristine and doped tubes. Then, the experimental setup and methodology is explained. Finally, the experimental results are analyzed in order to understand the new physics of Boron doped Single Walled Carbon Nanotubes, and answer the question of whether a controllable method has been developed to dope Carbon Nanotubes.

\section{Keywords}

Carbon Nanotubes; nanotechnology; Chemical Vapor Deposition; Raman Spectroscopy; X-Ray Photoelectron Spectra; Scanning Electron Microscopy 


\section{Contents}

1 Introduction 18

2 Overview of the Research Field 20

2.1. Carbon \& Carbon Nanotubes 20

2.1.1. Carbon Hybridization 20

2.1.2. Carbon allotropes 22

2.1.3. Carbon Nanotubes: Geometry and Classification 23

2.1.4. Types of doping 28

2.2. Carbon Nanotube Synthesis: an overview 30

2.2.1. Pristine Carbon Nanotube 31

2.2.2. Substitutional Doped Carbon Nanotubes synthesis 35

2.3. Analysis Techniques $\quad 36$

2.3.1. Raman Spectroscopy 36

2.3.2. X-ray Photoelectron Spectroscopy 38

2.4. Physical Properties of Carbon Nanotubes 38

2.4.1. Physical properties of pristine Carbon Nanotubes 39

2.4.2. Physical properties of Boron doped Carbon Nanotubes 50

2.5. Methods for doping characterization 53

3 Methodology $\quad 55$

3.1. Experiment proposal $\quad 55$

3.2. Experimental Description 56

3.2.1. Powder Catalyst synthesis 56

$\begin{array}{ll}\text { 3.2.2. Synthesis system } & 57\end{array}$ 
3.2.3. Synthesis Procedure

3.3. Characterization Methods 60

3.3.1. Raman Spectroscopy 61

3.3.2. X-Ray Photoelectric Spectroscopy 62

3.3.3. Scanning Electron Microscopy 63

4 Results 65

4.1. XPS 65

4.2. SEM+STEM 72

4.3. Raman 74

4.3.1. RBM Mode 74

4.3.2. D Band 76

4.3.3. G Band 77

$\begin{array}{ll}5 \text { Conclusion } & 81\end{array}$

6 Appendix 90 


\section{List of Figures}

Figure 1: This picture, adapted from [2], shows the geometric character of $s p$ hybridization: the symmetrical, and atom centered, $2 s$ and $2 p$ orbitals mix in order to create an orbital biased towards the neighboring atom, which attracts the electrons.

Figure 2: This figure is a possible geometry of a single-wall Carbon Nanotube (SWNT). It represents how the Nanotube structure can be understood as a rolled up version of a Graphene sheet. The vector $T$ represents the tube axis, whereas the vector $\mathrm{C}$ is the roll up direction. This way the point designated as $(6,3)$ will coincide with the $(0,0)$ point in the SWNT.

Figure 3: This figure represents Nanotube possible geometries as a function of graphene unit cell vectors. All named vertexes can be described as a sum of unit cell vectors $a_{1}$ and $a_{2}$. In the same way, the vector $C$ can be described as a sum of the unit cell vectors: $C=6 \cdot a 1+4 \cdot a 2$

Figure 4: Geometry and $3 D$ representation of an armchair tube on the left side; the same for a zigzag tube on the upper right side; a $(1,2)$ tube on the lower right side.

Figure 5: Examples of defects in Nanotubes. In (a) pentagon and heptagon defects responsible for the curvature in the tube. In (b), the transmission electron microscopy image of the corresponding MWNT curved, because of the latter effect. In (c), a Nanotube cap composed of a set of defects, which are responsible for the cap curvature. In (d), a pentagon-heptagon pair. Pictures (a) to (c) are from reference [5], and picture (d) is from reference [6].

Figure 6: These are examples of Nanotubes produced in this thesis, showing some kind of defect. The left picture shows a curving MWNT. This effect is caused by pentagon and heptagon defects in opposing sides of the tube. The right picture shows a bamboo-like MWNT. The bamboo-like Nanotube occurs might occur as a consequence of doping.

Figure 7: Illustration taken from [8], shows $-\mathrm{COOH}$ groups anchored onto a Single Walled Carbon Nanotube.

Figure 8: In this TEM image, taken from work [8], it can be seen a Nanotube filled with buckyballs, which can be identified as circular features inside the cylindrical structure of the Nanotube. 
Figure 9: Picture adapted from [11], is an example of substitutional doping of Nanotubes with Boron. In the picture, the black circles are Carbon atoms, while the green ones are Boron atoms, which assume in the Nanotube structure the place of Carbon atoms. The authors observe in their doped Nanotube samples the appearance of BC3 islands.

Figure 10: An example of arc discharge method. On the right-side panel, a schematic of the apparatus, and on the left-side panel, the material produced.

Figure 11: This Picture, taken from [30], illustrates the growth mechanism in the VLS model. The Carbon atoms from the feedstock diffuse into the liquid catalyst particle, and attach to the edges of the growing Nanotube.

Figure 12: This figure, modified from [44], shows the coordinate system in which Equation (11) is written in. In (a), the graphene structure on position space. In (b), the same structure but in wave vector space, and in hashed the first Brillion zone.

Figure 13: This figure, adapted from [44], is a drawing of dispersion relation in Equation (11). The left picture is a surface graph of the conduction (upper surface), and valence (lower surface) as a function of $k x$ and $k y$. On the top right picture, a section of the dispersion relation taken along the symmetry points $\Gamma$, $\mathrm{M}$, and $\mathrm{K}$ (along the blue line depicted both on the right panel and on the lower inset of the right panel).

Figure 14: This figure illustrates the quantization of the wave vectors with a $(6,0)$ zigzag tube. The chiral vector $C$ is drawn in blue, and the corresponding allowed wave vector lines (branches) are drawn in yellow, while an example of allowed wave vector is drawn in red.

Figure 15: This Picture, taken from [45], is what is known as Kataura plot. The transition energies are plotted as a function of SWNT diameter, and the different types of dots represent different chirality tubes. The white ones are semiconductor tubes, the black ones are metallic tubes, and the double circle (whit black circle inside) are armchair tubes. The areas designated as RhPd and NiY represents the diameter ranges of the tubes produced with the respective catalysts in the work by Kataura [45]. The horizontal lines highlight the laser energy ranges that would only detect metallic SWNTs for each the samples

Figure 16: A PL plot taken from [46]: on the horizontal axis the measured emission wavelength which is assigned to $E 11 S$; on the vertical axis the measured excitation wavelength, assigned to higher transition energies $E i i S, i \geq 2$.

Figure 17: This figure, taken from [53], shows experimental points fitted with the parameters $A=217.8 \mathrm{~cm}-1 . \mathrm{nm}$ and $B=15.7 \mathrm{~cm}-1$. 
Figure 18: This figure shows the construction of a Kataura like plot from reference [53]. On the left panel, the laser energies versus the measured Raman shifts. On the central panel, the horizontal axis is substituted by the inverse of Raman shift, for it should be proportional to diameter. On the right panel the theoretical Kataura plot. By comparing the right panel with the central one, the authors managed to identify each optical transition branch and the metallic/semiconductor character.

Figure 19: This figure, adapted from different figures of reference [55], illustrates the effect of SWNT diameter on $G+$ and $G-$ separation. On the left panel, experimental measurements of the peak positions. The black circles represent the peak positions of the semiconducting tubes, while the white ones, the metallic tubes. The upper circles are the $G+$ peak position, represented by $\omega G+$, and they are fitted by a constant line at $1591 \mathrm{~cm}-1$, while the bottom ones are the $G$ - peaks, represented by $\omega G$-, and are fitted by two different curves: one for the metallic tubes, the other for the semiconducting ones. On the center and right panels, the actual Raman spectra from which data was taken to make the plot on the left. It can be noted that as the RBM mode shifts to higher frequencies, the $G$ - peak shifts to lower frequencies, and the $G+$ does not move. It can also be noted the difference in $G$ - lineshape between semiconducting (lorenztian) and metallic (BWF) SWNTs. The peaks positions and bandwidths (in parenthesis) are in $\mathrm{cm}-1$ units

Figure 20: This figure, adapted from [58], shows the effect of Boron doping on the Optical Absorption Spectra. The two peaks assigned on the left side as E11S, and E22S correspond on the right panel to the smaller arrow and longer arrow transitions, respectively. On the right side, there are representations of energy dispersion relations (band structure), density of states (DOS), and the insets are a geometric representation of a unit cell of the SWNT, with Carbon atoms plotted as black circles, and Boron atoms plotted as white circles. The shaded areas in the DOS panels represent occupied electronic states. From (a) to (d) it is represented $0 \%, 6.25 \%, 12.5 \%$, and $25 \%$ doping.

Figure 21: This figure was taken from [60], and illustrated the G+ peak shift, when doping levels increase (left panel). Also, on the right panel, upshift on the peak position, is reported.

Figure 22: This figure is a schematic of the tube-KF25 adaptor. On the left side the quartz tube enters, sliding on the O-ring. On the right side, the KF25 flange allows the quartz tube to be linked to the rest of the vacuum system.

Figure 23: This figure shows how the quartz tube is designed so that it can easily be connected to a metallic KF16 flange. 
Figure 24: The complete assembly of the vacuum system. The numbers identify the components. (1) pump $B$, (2) gate valve, (3) mass flow controller, (4) valve, (5) precursor tube, (6) quartz tube adaptor, (7) furnace, (8) quartz tube, (9) needle valve, (10) pump A, (11) quartz crucible.

Figure 25: Spetrum B1s measured in XPS from material produced in Experiment Run 2. The peak is deconvolved in four componentes: B203, BC20/BCO2, magnesium-Boron-Oxygen compounds, and substitutional Boron in sp2 Carbon Nanotube lattice. The positions, bandwidths, and areas of the components are described in the topright inset. The light blue region in the graph highlights the peak region that was considered in the deconvolution.

Figure 26: X-Ray Photoelectron Spectrum measurement of $C 1 s$ peak from the same sample of Figure 25. The upper right inset describes the components used to deconvolve the peak, with the positions, bandwidths, and areas.

Figure 27: A graph of the "Yield Index" for the different Experiment Runs. The higher the "Yield Index" the higher should be the production yield of the sample. Experiment Run 11 is missing because no XPS measurement was done with the corresponding sample.

Figure 28: This image was taken in STEM mode, from sample produced in Experiment Run 1. The agglomerates of round material, can be identified as the support, $M g O$. In the center of the image, there is a tubular structure that can be a SWNT bundle or a MWNT.

Figure 29: Images taken from sample produced in Experiment Run 2. On the left picture, SEM image shows a high density of SWNTs. On the right picture, some SWNT bundles and possibly some individual SWNTs can be seen.

Figure 30: STEM images of Experiment Run 4 sample. On the left panel, there is a typical image of the sample. On the center panel, one can see some defective MWNTs, which will impact Raman spectra. On the right panel, there is a possibly SWNT bundle.

Figure 31: STEM images from sample produced in Experiment Run 7. On the left panel, there is a tubular structure, which might be a SWNT bundle or a MWNT. On the right panel, a multiwall Nanotube is imaged in detail, showing its inner compartmentalized morphology.

Figure 32: RBM mode for the different Experiment Runs. Each spectra represents a typical measurement for the corresponding Experiment Run. It can be noticed that some peak positions appear in more than one graph

Figure 33: The graph relates different precursor substances (and different Experiment Runs) to the corresponding $A D A G$ ratios. It can 
be noticed an increasing trend, as the precursor molecule decreases in size.

Figure 34: This graph is a Raman spectra measured around $D$ and $G+$ bands of sample produced in Experiment Run 2. The black line is the measured data, while the green curves are the Lorentzians that best fit data. The red line is the sum of the green curves. It should be noted that the $G$ band is not satisfactorily explained.

Figure 35: This graph shows the $G+$ peak position for each Experiment Run. Except for Experiment Run 8, there is a gentle downshift in $G+$ peak for the doped samples, in relation to the undoped one (Experiment Run 1).

Figure 36: Plot of the relative position of $G+$ peak of each Experiment Run in relation to the reference $G+$ peak position, Experiment Run 1. On the horizontal axis, doping as calculated in Table 5 is plotted. 


\section{List of Tables}

Table 1: This table, from [52] illustrates how one can assign chirality of an individual SWNT by knowing the RBM peak position, given a specific laser energy. After assignment, the author calculated the theoretical RBM position ("calc." column) and compared with the experimental value ("expt." column).

Table 2: This table presents the experiments done in this thesis. The first column identifies each experiment run number. In the second column, the abbreviations $\mathrm{TiB}, \mathrm{TeB}$, and $\mathrm{TmB}$ mean Triisopropyl, Triethyl, and Trimethyl Borate, respectively. The third column has the vapor pressures of the precursor liquids estimated at $23^{\circ} \mathrm{C}$, except for experiment run (6), where it is estimated at $2{ }^{\circ} \mathrm{C}$ (the liquid precursor is kept at this temperature in this run). The fourth column presents the pressure kept inside the vacuum chamber by the needle valve during synthesis step.

Table 3: This table presents some published component positions in the $B 1$ s peak.

Table 4: This table gives some published results on the positions of $01 \mathrm{~s}$ components positions as a function of chemical environment.

Table 5: this table related each precursor with its doping level, measured by the ratio of B-C component and C-C component, each normalized by its corresponding RSF factor.

Table 6: This table is a summary of the chemical composition of the samples.

Table 7: Mean and standard deviation values for the $B 1 \mathrm{~s}$ components taking into account all the Experiment Runs.

Table 8: Mean and standard deviation values for the $C 1 s$ components taking into account all the Experiment Runs.

Table 9: This table qualitatively assigns the possible chiralities associated with the Nanotubes produced in this thesis. Each pair $(n, m)$ defines a cell, which filled with the respective Nanotube diameter. The yellow, orange and pink cells correspond to the RBM resonance (or near-resonance) peaks: $156,5 \mathrm{~cm}-1$, $178,5 \mathrm{~cm}-1$, and $200 \mathrm{~cm}-1$ respectively. The boldface underlined cells correspond to the metallic tubes, which are more probably the ones in resonance with Raman laser. 


\section{List of Equations}

$\begin{array}{lr}\text { Equation (1) } & 20\end{array}$

$\begin{array}{ll}\text { Equation (2) } & 21\end{array}$

Equation (3) 22

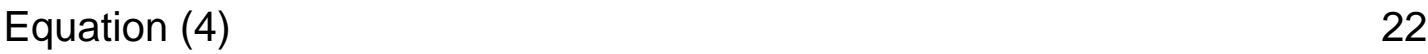

Equation (5) 25

$\begin{array}{ll}\text { Equation (6) } & 26\end{array}$

Equation (7) 26

$\begin{array}{ll}\text { Equation (8) } & 37\end{array}$

$\begin{array}{ll}\text { Equation (9) } & 37\end{array}$

Equation (10) 38

$\begin{array}{ll}\text { Equation (11) } & 40\end{array}$

$\begin{array}{ll}\text { Equation (12) } & 40\end{array}$

Equation (13) 42

Equation (14) 46

$\begin{array}{ll}\text { Equation (15) } & 49\end{array}$ 

Mas te darei a minha canção. Ministério Livres para Adorar, Vai Valer a Pena 